JURNAL ILMIAH MUQODDIMAH

Jurnal IImu Sosial, Politik, dan Humaniora

\title{
PEMBERDAYAAN PEMERINTAHAN DESA DALAM MEMBUAT PERATURAN DESA DI DESA BANDAR KHALIPAH KABUPATEN DELI SERDANG
}

\author{
Faiz Albar Nasution ${ }^{1}$, Zakaria Taher ${ }^{2}$ \\ Universitas Sumatera Utara \\ faiznasution92@gmail ${ }^{1}$ \\ rozafadhila@gmail.com²
}

\begin{abstract}
Abstrak
Pemerintahan desa merupakan bagian dari pemerintahan terendah didalam negara kesatuan Republik Indonesia. Peraturan desa yang terdapat dalam UU No. 6 tahun 2014, menjadi landasan yuridis bagi pemerintahan desa untuk mengurus rumah tangganya.oleh sebab itu,Pemerintahan Desa Bandar Khalipah dalam Mewujudkan Kewenangan Desa harus mampu menghasilkan peraturan desa yang menjadi landasan maupun pedoman dalam penyelenggara pemerintahan Desa Bandar Khalipah. Penelitian ini mencoba untuk menguraikan faktor-faktor apa saja yang membuat pemerintahan desa tidak berdaya dalam membuat Peraturan desa, menganalisis mengapa faktor tersebut berpengaruh dalam membuat peraturan desa dan usaha - usaha apa saja yang dilakukan pemerintah tingkat atas dalam memberdayakan pemerintah desa untuk membuat peraturan desa. Metode yang digunakan pada penelitian ini ialah deskriptif kualitatif. Teknik pengumpulan data diperoleh dari observasi, wawancara, buku, jurnal dan media online. Analisis data penelitian ini menggunakan reduksi data, display data dan menarik kesimpulan. Terdapat temuan penting terhadap faktor yang mempengaruhi Pemerintah desa tidak berdaya dalam membuat peraturan desa yaitu :Pertama, SDM, waktu dan dana. Kedua, hal tersebut dikarenakan pemerintah kecamatan tidak melakukan pembinaan dan pengawasan terhadap pemerintahan desa.
\end{abstract}

Kata kunci: Pemberdayaan, Pemerintahan Desa, Peraturan Desa

\begin{abstract}
Village government is part of the lowest government in the unitary Republic of Indonesia. The village regulations contained in Law No. 6 of 2014, became a juridical foundation for the Government of the village to take care of the household. Therefore, the government of Bandar Khalipah village in realizing the authority of the village should be able to produce village regulations Which is the foundation or guideline in the government organizer of Bandar Khalipah village. The research attempts to describe what factors make the village government incapacitated from creating village regulations, analyzing why the factor is influential in making the rules of the village and the efforts of what is done Government in empowering village governments to create village regulations. The method used in this research is a qualitative descriptive. Data collection techniques are obtained from observations, interviews, books, journals and online media. Analysis of this research data using data reduction, display data and draw conclusions. There are important findings to the factors that affect the village government is not empowered to make village regulations namely: First, HR, time and funds. Secondly, it is because the subdistrict government does not do construction and supervision over the village government.
\end{abstract}

Keywords: Empowerment, Village governance, village regulations 


\section{PENDAHULUAN}

Ketika berbicara tentang Desa di Indonesia, maka menimbulkan tiga macam pengertian. Pertama, secara sosiologis, kesatuan masyarakat atau komunitas penduduk yang tinggal dan menetap dalam suatu lingkungan, dimana antara mereka saling mengenal dengan baik dan corak kehidupan mereka relatif homogen. Kedua, secara ekonomi desa sebagai suatu lingkungan masyarakat yang berusaha memenuhi kebutuhan hidupnya sehari - hari dari apa yang disediakan alam dan sekitarnya. Ketiga, secara politik Desa sebagai suatu organisasi pemerintahan atau organisasi kekuasaan yang secara politis mempunyai wewenang (Maschab, 2013).

Secara historis Desa merupakan cikal bakal terbentuknya masyarakat politik dan pemerintahan di Indonesia jauh sebelum negara bangsa ini terbentuk. Struktur sosial sejenis Desa, masyakat adat dan lainnya, telah menjadi institusi sosial yang mempunyai posisi yang sangat vital. Hemat tersebut, dipengaruhi latar belakang Desa sebagai institusi yang otonom, adat istiadat dan relatif mandiri. Oleh karena itu, tingginya tingkat keragaman desa merupakan wujud bangsa yang paling kongret.

Ketika diberlakukannya UU No 6 Tahun 2014 tentang Desa, adalah sebuah konsekwensi logis bagi pemerintah daerah untuk memberdayakan aparat pemerintah Desa agar individu lebih mampu menjalankan tugas dan fungsinya sebagai birokrasi terdepan dalam penyelenggaraan pemerintahan Desa, pelaksanaan pembangunan Desa, pembinaan kemasyarakatan Desa dan pemberdayaan masyarakat Desa. Oleh sebab itu, sangat banyak sarat yang perlu diberdayakan terhadap aparat pemerintah Desa seperti: bagaimana aparat pemerintah Desa mampu membuat perencanaan pembangunan Desa, membuat peraturan Desa, mengelola dana dana Desa dan mengelola badan usaha milik Desa (DPRD Sumbawa, 2018). kewenangan

Desa dalam mengelola pembangunan, pembinaan dan pemberdayaan masyarakat, tentunya sangat berhubungan dengan peraturan Desa (Kushandajani, 2016). Peraturan Desa merupakan penjabaran lebih lanjut dari peraturan UU yang lebih tinggi dan tidak boleh bertentangan dengan kepentingan umum, serta harus memperhatikan kondisi sosial budaya masyarakat Desa setempat dalam upaya mencapai tujuan kemandirian Desa jangka panjang, menengah dan jangka pendek.

Dari hasil pra penelitan yang dilakukan oleh peneliti di Desa Bandar Khalipah, peneliti menemukan masalah yang dialami pemerintahan Desa Bandar Khalipah yaitu kurang optimalnya pemerintahan Desa dalam membuat peraturan Desa. Hal ini dapat dilihat dari Peraturan Desa yang dihasilkan pemerintah Desa Bandar khalipah Sejak Tahun 2014 - 2016 sebagai berikut :

1. Peraturan Desa Bandar Khalipah Nomor 01 Tahun 2014 Tentang Anggaran Pendapatan Dan Belanja Desa.

2. Peraturan Desa Bandar Khalipah Nomor 01 Tahun 2015 Tentang Anggaran Pendapatan Dan Belanja Desa.

3. Peraturan Desa Bandar Khalipah Nomor 02 tahun 2015 Tentang Kampoeng Hijau Dan Deli Serdang Berseri.

4. Peraturan Desa Bandar Khalipah Nomor 01 tahun 2016 Tentang Rencana Pembangunan Jangka Menengah Desa Tahun 2016 2021.

5. Peraturan Desa Bandar Khalipah Nomor 02 tahun 2016 Tentang Rencana Kerja Pembangunan Desa.

6. Peraturan Desa Bandar Khalipah Nomor 03 Tahun 2016 Tentang Anggaran Pendapatan Dan Belanja Desa.

Data tersebut, didapatkan dari Perdes dan hasil diskusi peneliti dengan Sekretaris Desa Bandar Khalipah. Keadaan tersebut, membuktikan pemerintah Desa belum berdaya dalam membuat Peraturan Desa. Hemat peneliti, berdasarkan UU 6 / 2014 yang 
JURNAL ILMIAH MUQODDIMAH

Jurnal IImu Sosial, Politik, dan Humaniora

mengharuskan pemerintah Desa dapat menyusun peraturan Desa seperti APBDES, RPJMDES, BUMDES, Kerja sama antar desa dan lain - lain. Namun peraturan Desa yang dihasilkan pemerintah Desa Bandar Khalipah hanya pokok - pokoknya saja, tanpa dibarengi peraturan Desa yang bertujuan untuk kemandirian Desa. Menyitir Friedman menjelaskan pemberdayaan tidak hanya berfokus kepada penguatan ekonomi, namun dapat pula aspek politis karena ia merupakan hasil interaksi antara konsep top down dan bottom up dalam upaya pertumbuhan masyarakat yang memusatkan terhadap pembangunan (Suprapto, 2008). Oleh sebab itu, menarik untuk mempelajari pemberdayaan pemerintah Desa Bandar Khalipah dalam membuat peraturan Desa.

Studi terdahulu telah banyak melakukan perhatian terhadap masalah pemerintah Desa dalam membuat peraturan Desa. Akan tetapi persoalan tentang Desa sampai saat ini masih menjadi masalah yang belum dapat diselesaikan. Fenomena tersebut, merupakan salah satu ciri ilmu sosial yang sangat dinamis dan terus berkembang. Oleh sebab itu, beberapa studi terdahulu yang dijadikan rujukan dalam penelitian ini sebagai berikut: hasil penelitian (Wijayanto, 2014) menunjukkan hubungan kerja Kepala Desa dengan BPD, meliputi tumpang tindih kewenangan antara Kepala Desa dengan BPD, pembentukan Peraturan Desa yang kurang professional dan lemahnya fungsi Legislasi BPD. Selanjutnya, hasil penelitian (Saputra, 2014) menjelaskan faktor - faktor yang mempengaruhi BPD dalam penyusunan dan penetapan Perdes ialah kesadaran masyarakat terhadap peraturan Desa, kualitas kinerja aparatur Desa, minimnya anggaran dalam menjalankan proses legislasi dan kurangnya kualitas internal BPD. Selain itu, hasil penelitian (Setiawati, 2018) memperlihatkan BPD belum melaksanakan tugas dan fungsinya secara maksimal, dipengaruhi kurangnya inisiatif dan koordinasi dengan pemerintahan Desa dalam membuat rancangan Peraturan Desa.

Selanjutnya, penelitian (Prasetya, 2016) tentang Peran BPD Dalam Mewujudkan Pembentukan Peraturan Desa yang Partisipatif menunjukkan ketua BPD di Desa Bojong menyarankan musyawarah Desa dalam membuat Peraturan Desa hanya formalitas, melihat mayoritas peserta seperti tokoh masyarakat, tokoh agama, tokoh pemuda, dan anggota BPD hampir selalu setuju dengan rancangan Peraturan Desa yang diusulkan oleh pemerintah Desa. Selain itu, penelitian (Mukri, 2018) mengidikasikan tiga faktor penyebab belum efektifnya peran BPD dalam penyusunan Peraturan Desa yaitu faktor SDM BPD, tidak adanya pelatihan khusus dan tidak ada anggaran yang dialokasikan. Kondisi serupa, terdapat hasil penelitian (Puansah, 2020) yang menunjukkan Kepala Desa, Aparatur Desa dan BPD belum memahami seutuhnya bagaimana penyelenggaraan Pemerintahan Desa berdasarkan asas Otonomi Desa dan Aparatur pemerintah Desa Tambiski Nauli, Kecamatan Naga Juang Kabupaten Mandailing Natal belum terberdayakan secara maksimal.

Penelitian yang dilakukan penulis pada dasarnya mengambil fokus yang berbeda, dimana penelitian ini menekankan "pemberdayaan pemerintahan Desa dalam membuat Peraturan Desa di Desa Bandar Khalipah". Penelitian tersebut, diharapkan bisa memberikan kontribusi kepada penelitian terdahulu, karena penelitian tersebut mempunyai kelebihan. Selanjutnya, urgensi penelitian akan menggambarkan, bagaimana relasi Kepala Desa Bandar Khalipah dan BPD dalam menjalankan masa jabatan, mewujudkan kewenangan Desa yang berdasarkan regulasi yang tepat dan bermanfaat. Hemat penulis bertujuan memberikan formulasi dalam pembangunan Desa kearah yang lebih baik. Oleh sebab itu, dapat disimpulkan peraturan desa menjadi hal yang paling mendasar dalam menjalankan pemerintahan Desa. Namun penyebab dari kurang 
JURNAL ILMIAH MUQODDIMAH

Jurnal IImu Sosial, Politik, dan Humaniora

efektifnya lembaga pemerintahan Desa dalam hal pembuatan Peraturan Desa perlu diketahui secara mendalam. Apakah hal ini dipengaruhi kurangnya kualitas sumber daya manusia, latar belakang pendidikan ataupun kurangnya bimbingan dari pemerintah Kecamatan. Beberapa masalah ini menjadi permasalahan yang harus dicarikan solusinya. Maka dari itu tujuan penelitian ini antara lain :

1. Ingin mengetahui faktor - faktor apa saja yang membuat pemerintahan desa tidak berdaya dalam membuat Peraturan desa.

2. Ingin menganalisis mengapa faktor tersebut berpengaruh dalam membuat peraturan desa.

\section{METODE}

Penelitian ini menggunakan pendekatan kualitatif deskriptif (Moleong, 2017). Penelitian ini dilakukan pada tahun 2017 dan fokus penelitian pada pemberdayaan pemerintahan desa dalam membuat peraturan desa. Lokus penelitian terdapat pada Desa Bandar Khalipah, Kec Percut Sei Tuan, Kab Deli Serdang. Mayoritas mata pencaharian penduduk desa Bandar Khalipah sebagai Karyawan perusahaan Swasta terdiri dari 2.679 Laki - laki dan 1.911 Perempuan dengan jumlah penduduk sebanyak 38.381 orang.

Penelitian ini mengunakan teknik analisis data kulitatif model Miles dan Huberman. Aktivitas dalam analisis data kuliatif secara interaktif dan berlangsung secara terus menerus sampai tuntas, sehingga datanya sudah lengkap untuk di analisis. Aktivitas tersebut meliputi : reduksi data, display data, dan penarikan kesimpulan (Miles, Huberman \& Saldana 2014).

\section{HASIL DAN PEMBAHASAN \\ Penyebab Pemerintahan Desa tidak Berdaya dalam membuat Peraturan Desa}

Pemerintahan Desa Bandar Khalipah dalam mewujudkan otonomi Desa dan kewenangan Desa, harus paham akan tugas dan tanggung jawab di bidang penyelenggara pemerintahan Desa, pelaksanaan pembangunan Desa, pembinaan kemasyarakatan Desa, dan pemberdayaan masyarakat Desa yang berdasarkan kepentingan masyarakat. Setiap penyelenggara Pemdes dalam menjalankan seluruh kegiatan yang ada di Desa harus memiliki landasan hukum dan tidak boleh sewenang - wenang. Landasan hukum tersebut berfungsi untuk memudahkan penentuan tugas pokok dan fungsi sekaligus menjadi batasan bagi aparat pemerintah Desa tentang apa yang boleh dan tidak boleh dilakukan (Awang, 2010). Akan tetapi, pemerintah Desa Bandar Khalipah menunjukkan ketidakberdayaan dalam Membuat peraturan Desa. Hal ini didasarkan dari peraturan Desa yang dihasilkan dari 2014 sampai 2016. Fenomena tersebut, memperlihatkan peraturan Desa yang dihasilkan Pemerintah Desa Bandar Khalipah hanya yang wajib saja. Adapun, Peraturan Desa yang dihasilkan seperti, APBDES, RPJMDES, RKPDES, Kampung Hijau.

Ketika Pemerintah Desa tidak berdaya dalam membuat Peraturan Desa, tentunya dipengaruhi beberapa faktor - faktor yang mendasari. Faktor tersebut antara lain : Pertama, SDM menjadi faktor yang paling dibutuhkan dalam Membuat Peraturan Desa. Merujuk pemikiran Gabriel Almond tentang struktur fungsional menjelaskan bahwa untuk dimungkinkannya merumuskan dan melaksanakan kebijaksanaan, maka sistem politik mempunyai lembaga lembaga atau struktur-struktur. Lebih lanjut, struktur lembaga akan mempengaruhi fungsinya dalam membuat kebijakan yang akan berdampak kepada masyarakat (Mas'oed, 2011). Oleh sebab itu, SDM yang baik akan menghasilkan Peraturan Desa yang baik juga. Dalam hal ini Aparatur Pemerintah Desa, BPD, Masyarakat Desa, Tokoh Adat, Tokoh Agama, dapat disebebut sebagai Struktur SDM yang memiliki fungsi di Desa Bandar Khalipah.

Akan tetapi, SDM Desa Bandar Khalipah belum optimal dalam membuat Peraturan Desa. Belum optimalnya SDM Desa Bandar Khalipah di latar belakangi pendidikan yang rendah, seperti masyarakat Desa yang tidak paham 


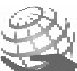

JURNAL ILMIAH MUQODDIMAH

Jurnal IImu Sosial, Politik, dan Humaniora

tugas dan fungsinya dalam partisipasi mereka untuk membuat peraturan Desa. Hemat tersebut, senada dengan Bpk Suparyono selaku Kepala Desa Bandar Khalipah yang mengatakan: "masyarakat desa Bandar khalipah belum cerdas dalam memahami fungsi dan manfaat peraturan Desa, ketika Pemerintah Desa ingin merancang atau membuat peraturan Desa mendapatkan penolakkan - penolakkan dari masyarakat Desa, hal ini dikarenakan banyaknya masyarakat Desa yang memiliki pendidikan rendah, maka dengan masalah seperti ini saya perlu memberikan sosialisasi lebih mendalam tentang peraturan Desa untuk menunjang partisipasi masyarakat". Stereotipe tersebut, menunjukkan bahwa SDM masyarakat Desa belum mumpuni, dipengaruhi pemerintah Desa tidak dapat memberdayakan masyarakat Desa. Selain itu, ketidakmampuan pemerintah Desa disebabkan tidak diberdayakan secara utuh oleh pemerintah daerah dan pemerintah pusat, seperti pendamping Desa yang sudah diamanatkan Undang - Undang tidak juga menjalankan Tugas dan fungsinya.

Selanjutnya, BPD sebagai garda terdepan dalam upaya menampung dan menyalurkan aspirasi masyarakat belum menjalankan tugas dan fungsinya. Ketidakaktifan BPD dapat dilihat dari peraturan desa yang dihasilkan. Hal ini dikarenakan Sulitnya mengajak pemangku struktur BPD untuk rapat dalam merancang peraturan Desa. Faktor tersebut dapat dibuktikan dengan pernyataan Ibu Lisma Aks, Selaku Sekretaris Bandar Khalipah yang mengatakan :"sulitnya mengajak BPD karena memiliki kesibukan masing masing, kesibukan tersebut dipengaruhi BPD mempunyai pekerjaan diluar sebagai BPD, pada akhirnya mengakibatkan Peraturan Desa yang dihasilkan belum efektif. Walau, BPD sudah diperhatikan pemerintah dengan diberikan honor, akan tetapi honor yang diperoleh sangat sedikit. $\mathrm{Hal}$ ini mengakibatkan BPD tidak menjalankan tugas dan fungsinya. Tidak adanya aspirasi masyarakat yang dilibatkan dalam membuat peraturan Desa dikarenakan BPD tidak memiliki pemahaman dalam membuat peraturan Desa".

Pendapat Sekretaris Desa cukup menjelaskan bahwa faktor yang menjadikan BPD tidak berdaya dalam membuat Peraturan Desa dipengaruhi BPD sibuk dengan Pekerjaan mereka diluar sebagai BPD. Masalah tersebut dapat dilihat dari Bpk Sakino selaku Ketua BPD memiliki pekerjaan sebagai Guru di sekolah swasta. Selain itu, faktor yang mempengaruhi BPD dalam menghasilkan peraturan Desa disebabkan tidak memiliki ide dalam membuat peraturan desa. Faktor tersebut, dipengaruhi minimnya bimbingan yang diberikan pemerintah tingkat atas terhadap BPD. Hemat tersebut, senada dengan Bpk, Sakino Selaku Ketua BPD Desa Bandar Khalipah yang mengatakan: "BPD sibuk dengan pekerjaaan diluar sebagai BPD, hal ini dikarenakan gaji yang didapatkan oleh BPD masih dibawah UMR yaitu 1,6 juta. Hal ini menjadi masalah mengapa BPD lebih mencari pendapatan lebih. Faktor lainnya, dikarenakan PAD Desa tidak ada yang mengakibatkan tidak adanya penghasilan dari Desa Bandar Khalipah. Pemahaman yang minim disebabkan minimnya pembinaan oleh pemerintah tingkat atas.

Stereotipe tersebut, menjelaskan

tidak berdayanya SDM BPD dipengaruhi minimnya pemberdayaan yang dilakukan pemerintah tingkat atas kepada BPD. Selain itu, keterbatasan Ketua BPD dalam menjabarkan informasi yang didapatkan dari hasil pelatihan, mengakibatkan peraturan Desa yang dihasilkan cukup memperhatinkan. Oleh sebab itu, dapat disimpulkan faktor yang mempengaruhi minimnya pembuatan peraturan desa dikarenakan ketidakmampuan BPD dalam membuat peraturan Desa.

Kedua, serangkaian Proses pembuatan Peraturan Desa memiliki waktu yang begitu panjang. Faktor tersebut dikarenakan tidak diperhitungkan dan ditargetkan dalam membuat Peraturan Desa. Masalah ini diakibatkan aparat desa sibuk dalam 
JURNAL ILMIAH MUQODDIMAH

Jurnal IImu Sosial, Politik, dan Humaniora

pekerjaannya sehari - hari sebagai perangkat Desa. Hemat tersebut didasarkan pendapat Ibu Lisma, Aks selaku Sekretaris Desa Bandar Khalipah yang mengatakan: "Waktu menjadi faktor kendala dalam membuat peraturan desa. Waktu yang begitu panjang dalam membuat peraturan Desa menimbulkan minimnya peraturan Desa yang dihasilkan di Desa Bandar Khalipah. Kondisi ini, disebabkan masing - masing aparat Desa memiliki rasa titik jenuh yang dipengaruhi kesibukan dalam pekerjaan yang di jalankan setiap hari. Apalagi dalam rapat - rapat tidak hanya berbicara tentang peraturan Desa tetapi banyak hal lainnya. Maka dari itu membuat peraturan Desa hanya pokok pokoknya saja".

Pendapat tersebut, cukup menggambarkan kesibukan aparat desa menjadi faktor yang mempengaruhi dalam membuat peraturan Desa. Dampak dari kseibukan perangkat Desa dengan pekerjaannya mempengaruhi peraturan Desa yang dihasilkan. Secara keberlanjutan masalah ini tidak hanya dilihat dari perangkat desa, namun juga kepada BPD yang tidak berdaya dalam membuat peraturan Desa. Masalah tersebut, menunjukkan perangkat Desa dan BPD tidak mampu mewujudkan otonomi Desa melalui peraturan Desa yang dihasilkan.

Ketiga, Dana menjadi faktor yang mempengaruhi dalam membuat peraturan Desa. Faktor tersebut, disebabkan tidak adanya PAD Desa yang berdampak terhadap sedikitnya pendapatan Perangkat Desa dan BPD. Selain itu, biaya rutin yang dijadikan keperluan sehari - hari seperti fotocopy, tinta tidak cukup. Keperluan ruitn tersebut, dikeluarkan 3 bulan atau 6 bulan sekali. Pendapat ini senada dengan Bpk, Sakino Selaku Ketua BPD yang menyebutkan:"Yang menjadi masalah Untuk keperluan kantor seharisehari tidak boleh diambil dari masyarakat seperti administrasi, seperti biaya rutin, dari pemerintah hanya 3 bulan atau 6 bulan sekali, terasa berat yang bekerja di kantor ini, pertama staf staf ini. Peraturan dari Kabupaten tidak boleh ada kutipan dari masyarakat, jadi masyarakat yang memiliki urusan hanya urusan seperti biasa saja. Contoh setiap warga urusan kepada kepala desa membayar 5000 tidak boleh".

Minimnya dana yang dihasilkan pemerintah desa hanya menjadi alasan aparat Desa untuk tidak bekerja secara optimal. Sejak UU No. 6 Tahun 2014 diterbitkan, alokasi dana Desa yang diberikan sudah cukup untuk memenuhi kebutuhan - kebutuhan Desa. Oleh sebab itu, hasil penelitian yang diperoleh dapat mempengaruhi pemerintah Desa Bandar khalipah dalam menjalankan urusan rumah tangganya agar mewujudkan otonomi Desa. Kondisi pemerintah Desa Bandar Khalipah yang tidak mengedepankan good governance, kedepannya harus menjadi lebih baik dalam Membuat peraturan Desa. Bahwasanya peraturan Desa yang baik hanya dapat diperoleh dari pemerintahan demokratis. Pemerintah yang demokratis terwujud apabila pemerintah desa mampu menjalankan tugas dan fungsinya dalam penyelenggara pemerintah Desa. Apabila hal ini dapat dilaksanakan, bukan tidak mungkin desa yang disebut daerah penuh dengan keterbelakangan dapat berubah menjadi desa yang lebih maju dan mandiri dalam mengurus rumah tangganya.

\section{SIMPULAN}

Peraturan Desa yang terdapat dalam UU No. 6 Tahun 2014 memberi peluang kepada pengaturan desa sesuai dengan hak asal usul. Dalam kasus di Desa Bandar Khalipah kasus pemberdayaan pemerintahan Desa dalam membuat peraturan Desa. Terdapat, dua hal penting yang menjadi penyebab utama pemerintahan Desa tidak berdaya dalam membuat peraturan desa. Penyebab tersebut antara lain: Pertama, faktor yang mempengaruhi pemerintahan desa tidak berdaya dalam membuat peraturan desa Yaitu: SDM, Waktu dan Dana. Kedua, faktor pemerintah Kecamatan tidak melakukan pembinaan dan pengawasan terhadap pemerintahan Desa. 
JURNAL ILMIAH MUQODDIMAH

Jurnal IImu Sosial, Politik, dan Humaniora

\section{DAFTAR PUSTAKA}

Buku:

Awang, A. (2010). Implementasi Pemberdayaan Pemerintah Desa. Yogyakarta: Pusataka Pelajar.

Mas'oed, M. (2011). Perbandingan Sistem Poltiik. Yogyakarta: Gadjah Mada University Press.

Maschab, M. (2013). Politik Pemerintahan Desa di Indonesia. Yogyakarta: Polgov.

Miles, M. B., Huberman, M. \& S. (2014). Qualitative Data Analysis: $A$ Methods Sourcebook. (H. Salmon, Ed.) (3rd ed.). London: SAGE.

Moleong, L. J. (2017). Metodologi Penelitian Kualitatif (27th ed.). Bandung: Remaja Rosdakarya.

Suprapto. (2008). Pemberdayaan Masyarakat Desa. Jakarta: Pustaka.

Jurnal:

Kushandajani. (2016). Implikasi UU NO. 6 Tahun 2014 Tentang Desa Terhadap Penyelenggaraan Pemerintahan Desa. Jurnal IImiah IImu Pemerintahan, 2(1), 53-64. Retrieved from https://ejournal2.undip.ac.id/index.p hp/jiip/article/view/1635

Mukri, A. (2018). Faktor-Faktor Penyebab Belum Efektifnya Peran Badan Permusyawaratan Desa Dalam Penyusunan Peraturan Desa (Studi Kasus di Desa Seri Kembang II Kecamatan Payaraman Kabupaten Ogan Ilir). JURNAL BHINNEKA TUNGGAL IKA, 5(1), 13-24. Retrieved from https://ejournal.unsri.ac.id/index.ph p/jbti/article/download/7895/pdf

Prasetya, A. F. (2016). Peran Badan Permusyawaratan Desa Dalam Mewujudkan Pembentukan Peraturan Desa yang Partisipatif di Kabupaten Lampung Timur. FIAT JUSTISIA., 10(3), 413-586. Retrieved from https://jurnal.fh.unila.ac.id/index.ph $\mathrm{p} /$ fiat/article/view/785/683

Puansah, I. (2020). Pelaksanaan Otonomi Desa Dalam Mewujudkan Pemberdayaan Aparatur Pemerintah Desa Tambiski Nauli, Kecamatan Naga Juang Kabupaten Mandailing Natal. JURNAL ILMIAHMUQODDIMAH: Jurnal IImu Sosial, Politikk Dan Humaniora, 4(1), 44-54. Retrieved from http://jurnal.umtapsel.ac.id/index.php/muqoddimah /article/view/1283

Saputra, P. (2014). Optimalisasi Peran Badan Permusyawaratan Desa Dalam Pembentukan Peraturan Desa (Studi Kasus Di Desa Tridayasakti Kecamatan Tambun Selatan Kabupaten Bekasi). UIN Syarif Hidayatullah Jakarta. Retrieved from http://repository.uinjkt.ac.id/dspace/ handle/123456789/25010

Setiawati. (2018). Peran Badan Permusyawaratan Desa Dalam Penyusunan dan Penetapan Peraturan Desa. Jurnal Pendidikan Kewarganegaraan, 5(1), 61-84. Retrieved from http://www.openjournal.unpam.ac.i d/index.php/PKn/article/view/1170/ 938

Wijayanto, : Dody Eko. (2014). Kepala Desa Dengan Badan Permustawaratan Desa Dalam Pembentukan Peraturan Desa. Jurnal Independent, 2(1), 40-50. Retrieved from http://jurnalhukum.unisla.ac.id/inde x.php/independent/article/view/17

Koran:

DPRD Sumbawa. (2018). Pemberdayaan Aparat Pemerintah Desa. Retrieved from http://www.dprdsumbawakab.go.id/opini/54/pembe rdayaan-aparat-pemerintah-desa/, hlm 1 